\title{
Impact of Small-Scale Irrigation on Household Food Security in Central Highlands of Ethiopia: Evidences from Walmara District
}

\author{
Gadisa Muleta $^{1 *} \quad$ Mengistu Ketema ${ }^{2} \quad$ Beyan Ahmed $^{3}$ \\ 1.Ethiopian Institute of Agricultural Research (EIAR), National Agricultural Biotechnology Research Center \\ (NABRC), P.O. Box. 249, Holeta, Ethiopia \\ 2.Ethiopian Economics Association, Addis Ababa, Ethiopia \\ 3.Department of Agricultural Economics, College of Agriculture and Environmental Science, P.O. Box 95, \\ Haramaya University, Dire Dawa Ethiopia
}

\begin{abstract}
Small-scale irrigation is among the feasible way in which agricultural production and productivity can be boosted to meet the ever-growing food demand of least developed countries like Ethiopia. But, unlike the potential, the level of utilization is very low. This study was conducted to assess the impact of small-scale irrigation on household food security using the primary data collected from 220 sample households from Walmara district, Finfinnee surrounding Oromia special zone. Descriptive and econometric data analyses were executed. Logistic regression was the model used and propensity score matching (PSM) was the method used to measure the impact of irrigation use on household food security. Using the result of PSM, 118 irrigation non-irrigators were matched with 83 irrigators by discarding 19 observations that are out of the common support. Then, the average treatment effect on the treated (ATT) was estimated and the result was $529 \mathrm{kcal}$. Finally, the sensitivity analysis was done and the result showed that the estimated ATT was insensitive to unobserved bias up to $200 \%$. This means family members of irrigation user households on average consume more calories of 529 kcal than irrigation non-users per day and this result is statistically significant. Therefore, agricultural policy interventions giving priority to small-scale irrigation facilities are recommended for their contributions in improving household food security in the study area. Keywords: Impact, Small-scale irrigation, Food security, Calorie, Walmara, PSM
\end{abstract}

DOI: $10.7176 / \mathrm{JESD} / 12-3-04$

Publication date: February $28^{\text {th }} 2021$

\section{INTRODUCTION}

Food insecurity and hunger are alarmingly increasing in the world. The number of people under acute food insecurity escalated from 80 million during 2015 to 108 million in 2016 and reached 124 million during 2017. Moreover, the figure of undernourished people in the world has also increased to more than 820 million from 804 million during the same years, indicating one person out of nine is undernourished. These figures are clearly showing that the achievements of the Sustainable Development Goal, specifically that of goal-2 (Hunger Eradication) is at risk (FAO et al. 2018; FSIN, 2019).

Conflicts, climate variabilities, and extremities (severe drought, floods, and storms) are the major driving factors behind global hunger and severe food crises. These problems are even worse in agrarian countries like those in Africa, in which the larger proportion of the population depends on agriculture (World Bank, 2018; World Vision, 2018). In Africa, about 20 percent of the population (257 million) were hungry, out of which 237 million were from sub-Saharan Africa during 2017. The prevalence of undernourished people in the region was escalated from 181 million in 2010 to 222 million in 2016 and then raised to more than 236 million during 2017 (FAO et al. 2018; FAO and ECA, 2018

Ethiopia is the second most populated country in Africa following Nigeria, having 105 million people estimated during 2017 (World Bank, 2019). Displacement induced by intercommunal clashes coupled with drought worsens the food and nutritional insecurity situation in the country and more than 8.1 million people need food assistance during 2019 (FAO, 2019). Though poverty reduction and human development efforts have contributed much to lift out human lives out of poverty, about 22 million people are still below the national poverty line during 2017. Even though the human development index (HDI) of the country is showing improvements, Ethiopia is yet among the poorest countries in the world, holding the rank of 173rd out of 189 countries (UNDP, 2018a).

To withstand the problems of recurrent drought and sustain the food security of the ever-growing population of the country, production and productivity-improving agricultural technologies with the existing resources like small scale irrigation are promoted for their contributions of increasing income and improving the livelihood of smallholders (Hirko et al. 2018; Tulu, 2014), creating employment opportunity, improving food security status, poverty reduction, production improvements, diversification of crops grown, improved household income, improved health status, source of a balanced diet, and easier access to medications, good sources of feeds for animals and good sources of asset ownership (Asayehegn, 2012).

Ethiopia has immense water resources from rivers, lakes, and ground which is 124.4, 70, and 30 billion cubic 
meters respectively (Berhanu et al. 2014). Out of these, the irrigation potential of major rivers and rift valley lakes is estimated to reach around 3,800,733 hectares of land (Ayalew, 2018). But, currently, 97 percent of cereal production in the country is being produced using rainfed, while irrigation is serving only 3 percent (FAO and IFC, 2015). The country also endowed 362,590 square kilometers of agricultural land and 15,119,000 hectares of arable land (CIA World Fact Book, 2019). The total irrigated land area in the country is recently increasing and reached 2.4 million ha in 2015 from 885,000 hectares during 2011 and the plan is to increase it to 4 million hectares by 2020 (ATA, 2016).

In the Oromia region, the trends of crop production are not rising with the pace by which the population growth is rising mainly due to recurrent drought. Therefore, using small-scale irrigation is the most feasible remedy to alleviate such problems and improving the production and productivity of small-holders, and also for improving their food security status. According to OIDA (2014), the Oromia region is endowed with an ample amount of irrigation water and irrigable land resources. But the level utilization is by far below the potential. Out of the total of 1.7 million hectares of irrigable land, only 800,000 hectares ( 47.05 percent) were irrigated yet both in traditional and modern schemes.

Similarly, according to the information obtained from the Walmara district agriculture and rural development bureau (2020), the district has a high potential for irrigation water and irrigable land. The estimated irrigation potential of the district is more than 9,055 hectares. Therefore, this study was conducted to assess the impact of small-scale irrigation on household food security in the study area.

\section{RESEARCH METHODOLOGY}

\subsection{Description of the study area}

The study was conducted in Walmara district, Finfinnee surrounding Oromia Special zone, Ethiopia. The district is located at $34 \mathrm{~km}$ to the west of Addis Ababa and lies between $8^{\circ} 50^{\prime}-9^{\circ} 15^{\prime} \mathrm{N}$ and $38^{\circ} 25^{\prime}-38^{\circ} 45^{\prime} \mathrm{E}$. The area of the district is 65,605 hectares, in which the majority part of the district (61 percent) is classified as highland and the rest ( 39 percent) is classified as mid-highland. The mean altitude of the district is 2400 meters above sea level, which is ranging from 2060 to 3380masl. The average annual rainfall of the district is 1,144 millimeters, ranging from 795 to 1300 millimeters. The annual temperature of the district also ranges from $6^{\circ} \mathrm{c}$ to $24^{\circ} \mathrm{c}$, and the average annual temperature is $14^{\circ} \mathrm{c}$. According to the population projection report of CSA (2019), the population of Walmara district was 112,498 , out of which 56,200 were male and 56,298 were female.

According to the information from the district office of agriculture and rural development, the farming system of the district is characterized as mixed, both crop and livestock production similar to other central highlands of the country. The major crops grown in the district during the main season are wheat, barley, tef, pulses, oilseeds, and potatoes respectively. These crops are the major staple food crops according to their orders in the study area. Similarly, the major vegetable crops grown during the off-season in the district using irrigation are potatoes, cabbages, tomatoes, carrots, and onions respectively.

\subsection{Description of irrigation schemes in the district}

Walmara district has different streams and rivers that are suitable for irrigation activities, out of which Holeta river is the main. The district has a long history in both traditional and modern irrigation schemes. The total irrigable land potential in the district is more than 9,055 hectares, out of which 7,580 hectares were cultivated yet under different types of irrigation. Out of the total irrigated land in the district, 828 hectares were cultivated using modern irrigation, 4,890 hectares were cultivated using traditional irrigation, 1,788 hectares were cultivated using motor pump irrigation, and 74 hectares were cultivated using wells. These irrigation types are currently serving more than 2,163 households living in the district.

Since Walmara district is among the surplus producing districts, and also among the high irrigation potential districts of the Oromia region, it was selected to be one of the agricultural growths and transformation program two (AGP II) districts and construction of modern irrigation schemes in different kebeles are being undertaken by this program. This study addressed three kebeles of having modern small-scale irrigation schemes (Talacho, Barfata Tokofa, and Bakaka \& kore odo) and one kebele with the traditional scheme (Wajitu Harbu).

\subsection{Sampling procedure}

Sample households were selected using a multi-stage sampling procedure. First, Walmara district was purposively selected. Second, kebeles in the district were classified into highland and mid-highland based on their ecology. Third, kebeles in each ecology were stratified into two based on irrigation access. Fourth, two kebeles from each ecology, a total of four kebeles were randomly selected from those kebeles having irrigation access. In the fifth stage, the representative sample households were selected using systematic random sampling.

The total sample size was determined by the rule of thumb that stating the minimum sample size should be ten times the number of included variables plus fifty and also ten percent contingency. Based on this, the total sample size was 220 households, out of which 121 households were non-irrigators and 99 households were 
irrigators. The sample size from each kebele was selected based on the proportional sampling method which is determined using the following formula:

Where $\mathrm{ni}$ - the sample to be selected from $\mathrm{i}^{\text {th }}$ kebele

$$
n i=\frac{(N i)(n)}{\Sigma N i}
$$

$\mathrm{Ni}$ - the total population living in $\mathrm{i}^{\text {th }}$ kebele.

$\Sigma \mathrm{Ni}$ - the summation of population living in selected four kebeles

$\mathrm{n}$ - total sample size for the district

Descriptive and inferential statistics were used to summarize the socio-economic variables included and econometric data analysis was performed to assess the impact of small-scale irrigation on household food security using logistic regression model, propensity score matching (PSM) method. Stata version 15.3 was the package used to perform data analysis.

\subsection{Sources of data and method of collection}

Both primary and secondary sources of data were used to collect data. Primary data were collected for sample households using questionnaires. Secondary data were collected from different sources like the district bureau of agriculture and rural development, published journals, kebele administration, etc.

\subsection{Method of data analysis}

\subsubsection{Descriptive data analysis}

Descriptive statistics like mean, percentage, standard deviation, maximum, and minimum were used to summarize the socio-economic variables. T-test and chi-square tests were performed to report the statistical significance of the continuous and dummy variables respectively. STATA V15.3 was the software used to analyze the collected data.

\subsubsection{Econometric data analysis}

Household food security was measured in both daily calorie intake (DCI) and food consumption score (FCS) and used as a dummy dependent variable to measure the impact of participation in small-scale irrigation on household food security. Logistic regression was the model used to estimate the propensity score (PS), which is the probability of participation in irrigation given observed covariates, that was used to match irrigation users and non-users in terms of daily calorie intake (DCI) and food consumption score (FCS). The functional form of the Logit model is expressed as:

For simplicity, it can be expressed as:

$$
\mathrm{Pi}=\mathrm{E}(\mathrm{D}=1 \mid \mathrm{Xi})=\frac{1}{1+e^{n-(\beta o+\beta i X i)}}
$$

$$
\mathrm{Pi}=\frac{1}{1+e^{-Z i}}
$$

The probability of participation in irrigation is expressed by equation 3 and also the probability of nonparticipation in irrigation can be expressed as:

$$
1-\mathrm{Pi}=\frac{1}{1+e^{Z i}}
$$

Similarly, the odds ratio in favor of participation in irrigation can be expressed as the ratio of the probability that the household participate in small scale irrigation to the probability that the household do not participate in small scale irrigation. This also can be expressed as:

Taking the natural Logarithm of equation 4, we get:

$$
\frac{P i}{1-P i}=\frac{1+e^{Z i}}{1+e^{-Z i}}=e^{Z i}
$$

$$
\mathrm{Li}=\ln \left[\frac{P i}{1-P i}\right]=\beta_{\mathrm{o}}+\beta_{1} \mathrm{X}_{1}+\beta_{2} \mathrm{X}_{2}+\beta_{3} \mathrm{X}_{3}+\ldots+\beta_{\mathrm{n}} \mathrm{X}_{\mathrm{n}}+\mathrm{U}_{\mathrm{i}}
$$

Where: $\quad \mathrm{Pi}$ - is probability of participation in irrigation

$\mathrm{Li}$ - is logarithm of odds ratio

$\beta_{1} \beta_{2} \beta_{3} \ldots \ldots \beta_{\mathrm{n}}$ are the coefficients to be estimated

$\mathrm{X}_{\mathrm{i}}$ - are the vectors of explanatory variables

$\mathrm{Ui}$ - is disturbance term

\section{RESULT AND DISCUSSIONS}

\subsection{Descriptive results}

\subsubsection{Descriptive Results of dummy variables}

Sex of the household head positively and significantly related to both household food security and participation in irrigation. As presented in Table 1, out of 99 irrigation user households, 11.11 percent were female headed and 88.89 percent were male headed households. This is to mean that male headed households are more irrigation users 
compared to female headed households. Similarly, out of 195 food secure sample households, 12.3 percent were female headed and 87.7 percent were male headed households, showing that male households are more food secure compared to female headed.

Credit access also positively and significantly related to both participation in irrigation and household food security. The result in Table 1 revealed that 95.9 percent of irrigation users have access to credit services, while 91.8 percent of irrigators are food secure. This is to mean that households having access to credit services are more likely to participate in small scale irrigation and to be food secure compared to households not having access to credit services.

Occurrences of crop pests negatively and significantly related to household food security and positively related to participation in small scale irrigation. As presented in Table 1, 46.6 percent of households whose crop fields were affected by crop pests were food secure and 57.6 percent of households whose crop fields affected by crop pests were irrigation users. From these results, households whose fields affected by crop pests are less likely to be food secure, but more likely to participate in irrigation. According to the responses from the sample households, households whose crop fields affected by pests during the main season tends to participate in smallscale irrigation during the off-season to compensate the yield loss during the main season.

Finally, access to extension contact positively and significantly related to household food security. From the result, 88.2 percent of households having access to extension contact were food secure.

Table 1. Descriptive results of dummy variables

\begin{tabular}{|c|c|c|c|c|c|c|c|c|c|c|c|c|c|}
\hline \multirow{3}{*}{\multicolumn{2}{|c|}{ Dependent }} & \multicolumn{12}{|c|}{ Dummy variables } \\
\hline & & \multicolumn{3}{|c|}{ Sex of the head } & \multicolumn{3}{|c|}{ Credit access } & \multicolumn{3}{|c|}{ Crop pests } & \multicolumn{3}{|c|}{ Extension contacts } \\
\hline & & Fem & Male & Total & $\mathrm{No}$ & Yes & Total & No & Yes & Total & $\mathrm{No}$ & Yes & Total \\
\hline \multirow{4}{*}{$\begin{array}{l}\text { Irrigation } \\
\text { use }\end{array}$} & No & 24 & 97 & 121 & 17 & 104 & 121 & 68 & 53 & 121 & 17 & 104 & 121 \\
\hline & Yes & 11 & 88 & 99 & 4 & 95 & 99 & 42 & 57 & 99 & 13 & 86 & 99 \\
\hline & chi $^{2}$ & & & 3.097 & & & 6.32 & & & 4.132 & & & 0.039 \\
\hline & Pr. & & & $0.078^{*}$ & & & $0.01 * *$ & & & $.042 * *$ & & & 0.843 \\
\hline \multirow{4}{*}{$\begin{array}{l}\text { Food } \\
\text { security } \\
\text { status }\end{array}$} & No & 11 & 14 & 25 & 5 & 20 & 25 & 6 & 19 & 25 & 7 & 18 & 25 \\
\hline & Yes & 24 & 171 & 195 & 16 & 179 & 195 & 104 & 91 & 195 & 23 & 172 & 195 \\
\hline & chi $^{2}$ & & & 16.636 & & & 3.57 & & & .626 & & & 4.941 \\
\hline & Pr. & & & $000 * * *$ & & & $.059 *$ & & -0 & $006 * * *$ & & & $0.026 * *$ \\
\hline
\end{tabular}

Note: $* * *$ and $* * *$ shows the significance levels at $10 \% 5 \%$ and $1 \%$

\subsubsection{Descriptive Results of continuous variables}

Age of the household head negatively and significantly related to both household food security and participation in irrigation. The mean age of food secure household was about 43 years while that of food insecure was about 49 year. Similarly, the mean age of irrigator households was 42 while that of non-irrigators was 45 years. From these results, aged households are less irrigators and less food secure compared to the younger household heads. This is as the result of aged households are less likely to adopt new technologies.

The educational status of the household head positively and significantly related to household food security. From the result in Table 2, the mean educational level of food secure households was 4, while that of food-insecure was 2 years of schooling. From this result, more educated household heads are more food secure compared to noneducated or less educated household heads.

The dependency ratio showed a strong negative relationship with household food security status. The mean dependency ratio for food secure households was 0.8 , while that of food-insecure households was 1.5. The households having more dependent family member are less food secure. This is because of dependency ratio will reduce the number of an active family member and also increase the burden of active family members to feed the dependent family members.

Livestock holding significantly related to household food security positively, and negatively to participation in irrigation. Food secure households own more than 7 livestock on average, while that food insecure own less than 6. Irrigator households own about 6 while non-irrigators own about 8 livestock measured in tropical livestock unit (TLU).

Family size negatively and significantly related to household food security, and positively and significantly related to participation in irrigation. The average family size for food secure households was about 5 persons, while that of food-insecure was about 6 . Irrigator households own 5 families on average, while non-irrigators own about 4. Large family households are less food secure, but more irrigation users.

Market distance negatively and significantly related to household food security. The mean market distance to food secure and insecure households were 5.3 and 6.3 respectively. This variable is not significantly different for irrigators and non-irrigators.

Irrigation distance negatively and significantly related to both household food security and participation in irrigation. The mean irrigation distance to food secure and insecure households was 2.1 and 2.6 kilometres 
respectively, while that of irrigators and non-irrigators were 1.9 and 2.3 kilometres respectively.

Land ownership showed positive relation to both household food security and participation in irrigation. Average land ownership for food secure and non-secure households were 1.5 and 0.6 hectares respectively, while it was 1.7 and 1.4 hectares for irrigators and non-irrigators respectively. Households having more land were more irrigators and also more food secure.

Table 2. Descriptive results of continuous variables by participation in irrigation and food security

\begin{tabular}{|c|c|c|c|c|c|c|c|c|c|c|}
\hline \multirow{2}{*}{ Variables } & \multicolumn{2}{|c|}{ Food secure } & \multicolumn{3}{|c|}{ Food insecure } & \multicolumn{2}{|c|}{ Irrigators } & \multicolumn{3}{|c|}{ Non irrigator } \\
\hline & mean & St.dev & mean & St.dev & t-value & nean & St.dev & mean & St.dev & $\mathrm{t}$-value \\
\hline Age of head (years) & 43.3 & 9.75 & 48.9 & 9.7 & $-2.7 * *$ & 42.3 & 10.4 & 45.4 & 9.2 & $-2.5 * *$ \\
\hline Education of head (years) & 4.3 & 3.9 & 2.36 & 2.9 & $2.37 * *$ & 4.5 & 4.0 & 3.7 & 3.7 & 1.38 \\
\hline Dependency & 0.82 & .68 & 1.5 & 0.7 & $-4.6 * * *$ & 0.9 & .62 & 0.9 & 0.8 & -0.31 \\
\hline Livestock (TLU) & 7.2 & 4.1 & 5.5 & 2.1 & $2.04 * *$ & 6.3 & 3.7 & 7.5 & 4.1 & $-2.2 * *$ \\
\hline Family size (AE) & 4.5 & 1.8 & 5.9 & 2.5 & $-3.7 * * *$ & 4.9 & 2.0 & 4.4 & 1.8 & $2.7 * *$ \\
\hline Off-farm income $1000 \mathrm{Bir}$ & 7.5 & 10.2 & 8.9 & 9.3 & -0.67 & 7.2 & 9.7 & 8.1 & 10.2 & 0.67 \\
\hline Market distance (KM) & 5.3 & 2.2 & 6.3 & 2.2 & $-2.16 * *$ & 5.2 & 2.3 & 5.5 & 2.1 & -1.30 \\
\hline Irrigation distance (KM) & 2.1 & 0.8 & 2.6 & .8 & $-2.61 * *$ & 1.9 & 0.8 & 2.3 & 0.7 & $-3.3 * * *$ \\
\hline Land owned (hectares) & 1.5 & 1.2 & 0.6 & 0.6 & $3.9 * * *$ & 1.7 & 1.2 & 1.4 & 1.2 & $2.3 * *$ \\
\hline
\end{tabular}

Note: $* *$ and $* * *$ shows the significance levels at $5 \%$ and $1 \%$

\subsection{Econometric results}

Logistic regression was used to estimate propensity score (PS). Participation in irrigation used as dummy dependent variable and as independent, 13 variables were included. As stated in Bernard et al (2007), conditional on the ability of propensity score to overcome potential sources of bias, program participant and non-participant become comparable.

Table 3. Logistic regression result of estimation of propensity scores

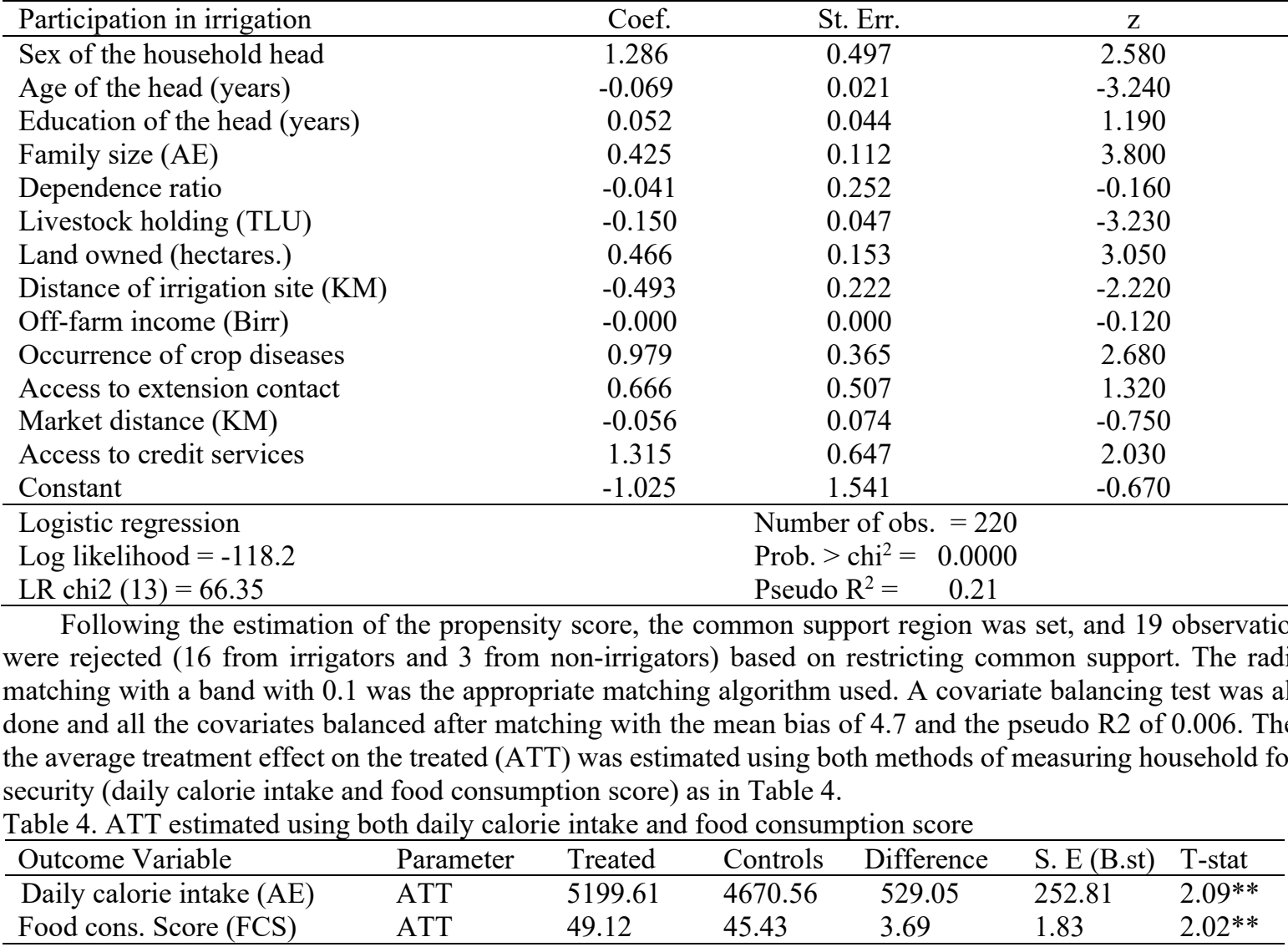

\section{Note: $* *$ shows that the variable is significant at 5 percent probability level}

Finally, the sensitivity analysis was done and the result revealed that the estimated average treatment effect on the treated was not sensitive to unobserved bias up to $200 \%$. Therefore, as presented in Table 4 , the calorie amounting $529 \mathrm{kcal}$ was the pure effect of participation in small scale irrigation and this means, household members 
of irrigation users on average consumed more energy of 529 kilocalories than the family members of irrigation non-users and this difference was significant at 5 percent. This result is similar to the results reported by Beneberu and Biazin, 2020 and Abdisa et al. 2017

Similarly, household members of irrigation users have a better food consumption score profile than irrigation non-users, and the difference is 3.69 on average, and this difference was significant at 5 percent probability level. Therefore, controlling for pre-intervention differences using propensity score matching, participation in small scale irrigation improved household food security measured in both daily calorie intake and household food consumption score.

\section{CONCLUSION}

The study was conducted with the main objective of assessing the impact of small-scale irrigation on household food security in Walmara district, central highlands of Ethiopia. A multi-stage sampling technique was employed to select 220 sample households from four randomly selected kebeles. Logistic regression and propensity score matching were used for econometric data analysis.

The descriptive result showed that the sex of the household head, access to credit services, occurrence pf crop pests and diseases, age of the household head, livestock holding, family size, irrigation distance and land ownership were the variables that showed a significant relation with irrigation participation. Similarly, sex, credit access, crop disease, extension contact, age, education, dependency, livestock holding, family size, market distance, irrigation distance and land ownership were the variables that significantly related to household food security.

To assess the impact of small-scale irrigation on household food security, the propensity score was estimated and the common support region was restricted. Based on this common support, 118 irrigation non-users were matched with 83 irrigation users by discarding 19 observations that are out of the common support. The matching qualities were checked using pseudo R2 which is 0.006 , matched sample size which is 201 and the number of balanced covariates which was 13. Finally, the ATT was estimated.

The estimated ATT revealed that both methods of measuring household food security (individual's daily calorie intake and food consumption score) showed a significant mean difference for irrigation users and nonusers. On average, a family member of irrigation user households consumes more calorie of 529 kcal than the family member of irrigation non-users, which is a statistically significant difference. Similarly, irrigation user households have a better food consumption score profile than irrigation non-users, and on average, irrigation user households got 3.69 more value of food consumption score, which also a statistically significant difference.

Therefore, government policies and strategies (agricultural policies and strategies) focusing on promoting small scale irrigation should be implemented to take out the lives of millions of small-holder farmers from the state of food insecurity and poverty, especially in erratic rainfall and drought-prone areas of the country.

\section{REFERENCES}

Abdissa F, Tesema G, Yirga C (2017) Impact Analysis of Small-Scale Irrigation Schemes on Household Food Security the Case of Sibu Sire

District in Western Oromia, Ethiopia. Irrigat Drainage Sys Eng 6: 187. doi: 10.4172/2168-9768.1000187

Asayehegn, K., 2012. Negative impact of small-scale irrigation schemes: A case study of Central Tigray regional state, Ethiopia. Agric Res Rev, 1(3), pp.80-85.

ATA, 2016. Ethiopian Agricultural Transformation Agency Annual Report. Addis Ababa, Ethiopia.

Beneberu, A., and Biazin A., 2020. Small-scale irrigation and its effect on food security of rural households in North-West Ethiopia: A comparative analysis

DOI: https://dx.doi.org/10.4314/ejst.v13i1.3

Berhanu, B., Seleshi, Y. and Melesse, A.M., 2014. Surface water and groundwater resources of Ethiopia: potentials and challenges of water resources development. In Nile River Basin (pp. 97-117). Springer, Cham.

Bernard, T., Taffesse, A.S. and Gabre-Madhin, E., 2008. Impact of cooperatives on smallholders' commercialization behavior: evidence from Ethiopia. Agricultural Economics, 39(2), pp.147-161.

CIA World Fact Book, 2019. Ethiopia- United States Central Intelligence Agency. https://www.cia.gov/library/publications/the-world-factbook/geos/et.html

CSA, 2017. Central Statistical Agency. The Federal Democratic Republic of Ethiopia, Central Statistical Agency, Agricultural Sample Survey 2016/7 (2009 E.C.), Volume I, Report on Area and Production of Major Crops (Private Peasant Holdings, Meher Season), Statistical Bulletin 532, May 2017, Addis Ababa, Ethiopia.

FAO and ECA, 2018. Regional Overview of Food Security and Nutrition. Addressing the threat from climate variability and extremes for food security and nutrition. Accra. $116 \mathrm{p} \mathrm{p}$

FAO and IFC, 2015. Irrigation Market Brief of Ethiopia. Food and Agriculture Organization of the United Nations. Rome, Italy.

FAO, 2019. Early Warning Early Action report on food security and agriculture (April-June 2019). Rome. 62 pp. License: CC BY-NC-SA 3.0 IGO 
FAO, IFAD, UNICEF, WFP and WHO. 2018. The State of Food Security and Nutrition in the World 2018. Building climate resilience for food security and nutrition. Rome, FAO. License: CC BY-NC-SA 3.0 IGO.

FSIN, 2019. Food Security Information Network, Global Report on Food Crises: Joint Analysis for Better Decisions.

Hirko, T., Ketema, M. and Beyene, F., 2018. Evaluating the impact of small-scale irrigation practice on household income in Abay Chomen District of Oromia National Regional State, Ethiopia. Journal of Development and Agricultural Economics, p.384.

OIDA, 2014. Oromia Irrigation Development Authority (OIDA). Guidance for Irrigation Development Project. May 2014.

Tulu, H., 2014. The Effects of Small-Scale Irrigation on Rural Households 'income: The Case of Adami Tulu Jido Kombolcha District, Oromia National Regional State.

UNDP, 2018a. Ethiopia's Progress Towards Eradicating Poverty: Implementation of the third United Nations decade for Eradication of Poverty $(2018$ - 2027).

UNDP, 2018b. Human Development Indices and Indicators: Briefing notes on 2018 Statistical Updates of Ethiopia

World Bank, 2018. Ethiopia's Economic Update. The Inescapable Manufacturing-Services Nexus: Exploring the potential of distribution services.

World Bank, 2019. An Overview of Ethiopian Economy. World Bank's goals of promoting rapid economic growth and improving service delivery.

World Vision, 2018. East Africa's hunger crisis situation report. Responding to Food Insecurity in Ethiopia. March 01-31, 2018. 